\title{
Construction and evaluation of a gfp-tagged Salmonella Typhimurium strain for environmental applications ${ }^{\#}$
}

\author{
LM Burke ${ }^{1}$, VS Brözel ${ }^{2}$ and SN Venter ${ }^{3 *}$ \\ ${ }^{1}$ Division of Natural Resources and the Environment, CSIR, Pretoria 0001, South Africa \\ ${ }^{2}$ Department of Biology and Microbiology, South Dakota State University, Brookings, SD 57007, USA \\ ${ }^{3}$ Department of Microbiology and Plant Pathology, University of Pretoria, Pretoria 0002, South Africa
}

\begin{abstract}
Salmonella enterica ser. Typhimurium was isolated from freshwater sediments and chromosomally labelled with a stable variant of the green fluorescent protein (GFP). The pUT mini-Tn $5 \mathrm{Km}$ transposon was used to introduce the $g f p$ gene onto the chromosome of the $S$. Typhimurium strain by tri-parental mating. Southern Blot hybridisation confirmed that the gene had integrated into the chromosome. The $g f p$ gene was stably maintained and the labelled strain was not growth-rate impaired. The incorporation of the $g f p$ gene did not convey any significant loss of phenotype which would affect the survival and behaviour of the tagged strains. The tagged S. Typhimurium strain was used to spike an established drinking water biofilm and was able to colonise and persist within the biofilm. The tagged strain was also successfully used to study the survival of $S$. Typhimurium in natural sediments under different temperatures. These tagged strains can therefore be used to study the fate and survival of different Salmonella strains in water environments.
\end{abstract}

Keywords: biofilm, green fluorescent protein, Salmonella Typhimurium, survival

\section{Introduction}

Salmonella enterica is a primary agent of gastroenteritis in both humans and animals and each year an estimated 12.5 million people are affected (Hunter, 1997). Although often associated with food-borne transmission, Salmonella is also frequently isolated from water sources, which may serve as a reservoir for infection. Salmonella have been detected in sewage, freshwater, marine, coastal and groundwater (Baudart et al., 2000; Ho and Tam, 2000; Gannon et al., 2004). The presence of this bacterium in the aquatic environment is often linked to direct or indirect contamination by human or animal excretion (Baudart et al., 2000; O'Shea and Field, 1992; Moganedi et al., 2007).

Compared to E. coli, Salmonella appears to withstand a wider variety of environmental fluctuations and may persist in various water environments for extended periods. (Winfield and Groisman, 2003). Biofilms of potable water distribution systems have the potential to harbour Salmonella. This is problematic, as these pathogens could be released back into the flow following detachment (Camper et al., 1999; Szewyk et al., 2000). Sediments may protect enteric bacteria from certain stressors associated with aquatic environments and they are known to act as nutrient sources that may support bacterial growth (Lim and Flint, 1989). Salmonella enterica serovar Typhimurium mr-DT104 was found to survive for several months in aquatic environments, with enhanced survival in sediments relative to overlying water (Moore et al., 2003). In order to protect and manage the quality of water sources, a clear understanding of the fate, survival and transport of this bacterium in various aqueous environments is necessary.

\footnotetext{
\# Journal series publication 3595 from the South Dakota Agricultural Experiment Station.

* To whom all correspondence should be addressed.

푱 +27 12 420-4100; fax: +27 12 420-3266;

e-mail: fanus.venter@up.ac.za

Received 10 September 2007; accepted in revised form 11 December2007.
}

Detailed studies on the fate and persistence of non-typhoidal Salmonella in water environments have been limited due to the lack of a stably tagged strain readily distinguishable in vivo from the rest of the bacterial community. A range of specific detection techniques has been described in the past decades, including use of fluorescent antibodies (Cloete and De Bruyn, 2001) and fluorescent in situ hybridisation (FISH) (Amann et al., 1995). Genetic tags described include the luciferase (lux) operon (Meikle et al., 1994), the expression of which exerts significant energy drainage on the cell. A more recent approach to study the behaviour of a specific strain in natural environments is by tagging the bacterial cell with the gene encoding the green fluorescent protein (GFP) (Möller et al., 1998). GFP can be visualised by epi-fluorescence microscopy, fluorescing green during excitation with UV or blue light. The $g f p$ gene obtained from the jellyfish Aequorea victoria (Chalfie et al., 1994) overcomes many of the limitations posed by systems such as luciferase and end-point approaches such as FISH. Cells tagged with $g f p$ therefore do not require prior fixing, staining or addition of substrate for visualisation (Chalfie et al., 1994; Valdivia et al., 1996). GFP is a very stable protein (Andersen et al., 1998) and its detection is independent of cellular energy reserves at the time of viewing. Green fluorescence phenotypes are detectable in all growth phases even under starved conditions (Tombolini et al., 1997). Frana and Carlson (2001) developed and used a plasmid encoding gfp in Salmonella Typhimurium phagetype DT104. It was found that fluorescence was maintained for up to 50 propagations under non-selective conditions. For strains that are destined for use in an environmental study, it is imperative that the desired traits are encoded and maintained on the chromosome, ensuring stability of the engineered phenotype (Eberl et al., 1997). The chromosomal tagging of bacterial strains using GFP allows for the possibility of performing survival studies under mixed culture conditions including temporal observations over extended periods of time. In this way, a more realistic indication of the growth potential of Salmonella in aquatic environments can be obtained due to the interaction with competing indigenous micro-organisms. 
The aim of this investigation was to chromosomally tag a clinically relevant Salmonella strain isolated from an aqueous ecosystem with the $g f p$ gene. The stability of maintenance, expression of $g f p$, and its suitability for application in studies of biofilms and freshwater sediments is demonstrated.

\section{Experimental}

\section{Isolation and identification of Salmonella strains}

Sediment samples were collected from rivers in the Vhembe region of the Limpopo Province of South Africa. After preenrichment in buffered peptone water (BPW) (Oxoid) for $24 \mathrm{~h}$ at $37^{\circ} \mathrm{C}, 1 \mathrm{~m} \ell$ of the pre-enrichment was inoculated into $9 \mathrm{~m} \ell$ of Rappaport-Vassiliadis (RV) broth (Oxoid) for selective enrichment and incubated for $24 \mathrm{~h}$ at $42^{\circ} \mathrm{C}$. A loop-full of broth from each positive tube was plated onto XLD (xylose lysine deoxycholate) agar (Oxoid) and incubated at $37^{\circ} \mathrm{C}$ for $24 \mathrm{~h}$. Black colonies were identified using the API $20 \mathrm{E}$ biochemical test strips (bioMérieux). Serological typing of selected isolates was performed at the ARC-Onderstepoort Veterinary Institute, Pretoria, South Africa. Care was taken to select for environmental strains that belonged to Salmonella serotype Typhimurium, as it is the most commonly isolated serotype from patients in this area. Isolates were maintained on Microbank beads (Pro-lab diagnostics) at $-80^{\circ} \mathrm{C}$.

\section{Chromosomal tagging}

S. ser. Typhimurium isolates were confirmed susceptible to ampicillin $(100 \mu \mathrm{g} / \mathrm{m} \ell)$ and kanamycin $(100 \mu \mathrm{g} / \mathrm{m} \ell)$ using Luria Bertani (LB) agar. The pUT mini-Tn5 Km transposon (De Lorenzo et al., 1990) was used to insert the gfpmut3b* gene into the chromosome. Salmonella was transformed by tri-parental mating using E. coli HB101 (pRK2013) (Figurski and Helinski, 1979) as

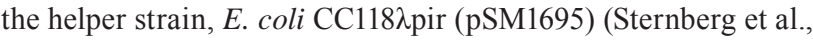
1999) as the donor strain and a Salmonella isolate as the recipient (Table 1). A loop-full of each of the donor, helper and recipient strains was mixed together on LB agar and incubated for $24 \mathrm{~h}$ at $37^{\circ} \mathrm{C}$. The mixed culture was then streaked onto XLD agar supplemented with $100 \mu \mathrm{g} / \mathrm{m} \ell$ of kanamycin and incubated at $37^{\circ} \mathrm{C}$ for $24 \mathrm{~h}$. Black colonies were selected and confirmed as tritransconjugants by their ability to fluoresce green when exposed to blue light. Confirmed tri-transconjugant colonies were inoculated into $10 \mathrm{~m} \ell$ of $\mathrm{LB}$ broth and incubated at $37^{\circ} \mathrm{C}$. Chromosomal integrants were selected by replica-plating kanamycinresistant colonies onto ampicillin agar and selecting sensitive colonies. The presence of $g f p$ was confirmed by fluoresecence microscopy using an inverted Zeiss Axiovert 200 fluorescent microscope (Excitation - $490 \mathrm{~nm}$ and Emission - $510 \mathrm{~nm}$ ), fitted with a $100 \mathrm{x} / 1.4$ Zeiss Neofluor objective. The images were captured using a Nikon charge-coupled device (CCD) camera.

\section{Verification of chromosomal tagging}

Chromosomal DNA was extracted from two tagged isolates, the wild-type strain and the donor strain using the Dneasy tissue kit (Qiagen). The $g f p$ gene of 720 bp was amplified by PCR using the primers $P_{\text {gfp (up) }}$ (5'-ATATAGCATGCGTAAAGGAGAAGAACTTTTCA- 3') and $\mathrm{P}_{\text {gfoum }}$ (5'-CTCTCAAGCTTATTTGTATAGTTCATCCATGC- 3') (Andersen et al., 1998). The $50 \mu \ell$ PCR reaction mixture contained $50 \mathrm{pmol} / \mu \ell$ of each primer, $2.5 \mathrm{mM}$ deoxynucleotide triphosphate (dNTP), $5 \mu \ell$ of $10 \mathrm{x}$ PCR buffer (containing $15 \mathrm{mM} \mathrm{MgCl}$ ), $1 \mathrm{U}$ of Taq polymerase and 50 to $100 \mathrm{ng}$ of genomic template DNA. The reaction mixture was subjected to 30 amplification cycles of $92^{\circ} \mathrm{C}$ for $1 \mathrm{~min}, 60^{\circ} \mathrm{C}$ for $1 \mathrm{~min}$, and $72^{\circ} \mathrm{C}$ for $1 \mathrm{~min}$ on a GeneAmp ${ }^{\circledR}$ 2700 PCR System (Applied Biosystems). An initial start of $92^{\circ} \mathrm{C}$ for $5 \mathrm{~min}$ and a final elongation step at $72^{\circ} \mathrm{C}$ for $5 \mathrm{~min}$ was also included. Southern Blot hybridisation was performed using the $g f p$ gene as amplified by PCR from pSM1695 as a probe. The amplicon was excised from an agarose gel using the QIAquick ${ }^{\circledR}$ PCR purification kit (Qiagen) and random primed with digoxygenin using the DIG High Prime DNA Labelling and Detection Starter Kit I (Roche). Southern blotting was performed using the protocol as supplied by Roche, transferring agarose-resolved DNA extracts to Hybond ${ }^{\mathrm{TM}}-\mathrm{N}+$ nylon membrane (Amersham) by vacuum and hybridising at $64^{\circ} \mathrm{C}$ using $20 \mathrm{ng}$ of probe DNA. Hydridised probe was detected chromogenically using NBT/BCIP (Roche).

\section{Survival studies}

\section{Stability and maintenance of the gfp gene}

Tagged strains and the wild-type strain were inoculated separately into $10 \mathrm{~m} \ell$ of $\mathrm{LB}$ or ${ }^{1 /} / 10$ strength $\mathrm{R} 2 \mathrm{~A}$ broth and incubated at $37^{\circ} \mathrm{C}$ while shaking at $180 \mathrm{r} / \mathrm{min}$. Aliquots of $100 \mu \ell$ were transferred axenically to fresh broth daily for $30 \mathrm{~d}$. The expression and stability of the $g f p$ gene in cells were verified by fluorescence microscopy

\section{Fitness of the gfp-tagged strain}

The wild-type and tagged strains were cultured overnight in LB broth. One $\mathrm{m} \ell$ of the overnight culture was inoculated into

\begin{tabular}{|c|c|c|}
\hline \multicolumn{3}{|c|}{$\begin{array}{l}\text { TABLE } 1 \\
\text { Strains and plasmids used for tri-parental mating }\end{array}$} \\
\hline Strains and plasmids & Relevant characteristics & Reference or source \\
\hline \multicolumn{3}{|l|}{ E. coli K-12 strains } \\
\hline HB101 & E. coli K-12/B hybrid & JB Andersen (personal gift) \\
\hline 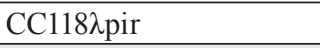 & $\lambda$ pir lysogen & JB Andersen (personal gift) \\
\hline \multicolumn{3}{|l|}{ Salmonella strains } \\
\hline S. Typhimurium & Recipient strain; environmental isolate & This study \\
\hline Tagged $S$. Typhimurium & 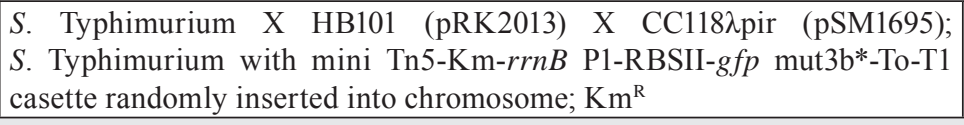 & This study \\
\hline \multicolumn{3}{|c|}{ ( } \\
\hline pRK2013 & RK2 transfer function; helper plasmid in tri-parental matings & Figurski and Helinski, 1979 \\
\hline pSM1695 & $\begin{array}{l}\mathrm{Amp}^{\mathrm{R}} \mathrm{Km}^{\mathrm{R}} \text {; delivery plasmid for mini Tn5-Km-rrnB P1-RBSII- } g f p \\
\text { mut3b*-To-T1 }\end{array}$ & Sternberg et al., 1999 \\
\hline
\end{tabular}


$250 \mathrm{~m} \ell$ side-arm flasks containing $100 \mathrm{~m} \ell \mathrm{LB}$ or $1 / 10^{1 /}$ strength $\mathrm{R} 2 \mathrm{~A}$ broth and incubated while shaking at $37^{\circ} \mathrm{C}$. The OD at 600 $\mathrm{nm}$ was determined spectrophotometrically. Phenotype Microarrays (Biolog) were used to compare the phenotypic profiles of the wild type and tagged Strain 1. The absorbance at $590 \mathrm{~nm}$ was determined after $24 \mathrm{~h}$ using an $\mathrm{EL}_{\mathrm{x}} 800$ Universal Microplate Reader (Bio-Tek Instruments Inc.).

\section{Fate of Salmonella in an established biofilm}

A flow cell was used to simulate biofilm formation in a water distribution system. The cell, having 6 channels with an individual dimension of $2 \times 2 \times 15 \mathrm{~mm}$ was covered with a glass cover-slip applied with silicone sealant $\left(\right.$ Bostik $\left.^{\circledR}\right)$ and connected to a Watson Marlow 205S peristaltic pump. The system was sterilised by perfusing with bleach $(2 \%)$ and rinsed with sterile $\mathrm{dH}_{2} \mathrm{O}$. A simulated drinking water biofilm was established in sterile tap water supplemented with $1 \mathrm{mg} / \ell$ acetate by inoculating the flow cells with a mixture of 5 non-fluorescing isolates obtained from biofilms of drinking water systems. Flow was paused for $1 \mathrm{~h}$ to allow bacteria to attach to the glass slide and then set at a flow rate of $0.4 \mathrm{~mm} / \mathrm{s}$ through the flow cell. After $72 \mathrm{~h}$, flow cells were spiked with $g f p$-tagged Salmonella pregrown in ${ }^{1 / 1}$ strength R2A medium and diluted to $10^{6}$ and $10^{2}$ $\mathrm{CFU} / \mathrm{m} \ell$ respectively. The flow was maintained for a further 144 $\mathrm{h}$ and the biofilms were viewed periodically by phase contrast and epifluorescence microscopy.

\section{Survival of Salmonella in natural freshwater sediments}

Sediment samples of $500 \mathrm{~m} \ell$ were collected from a small stream near Thabazimbi, Limpopo Province, South Africa, which forms part of the Limpopo basin. The sediment was confirmed free of Salmonella by the MPN method using BPW followed by RV broth and streaking onto XLD agar (detection limit 0.3 $\mathrm{CFU} / \mathrm{m} \ell$ ). The sediment samples were mixed with $24 \mathrm{~h} \mathrm{LB}-$ grown recombinant 1 Salmonella, washed and resuspended in PBS to a final density of $10^{9}$ cells/g of sediment. The spiked sediment microcosms were incubated at 8,16 and $28^{\circ} \mathrm{C}$, and the number of recoverable tagged isolate was determined every $7 \mathrm{~d}$ for 23 weeks. Salmonella was enumerated by re-suspending $10 \mathrm{~g}$ of sediment in $90 \mathrm{~m} \ell$ of extraction buffer $(0.04 \mathrm{~g}$ EGTA, $0.12 \mathrm{~g}$ TRIS, $0.1 \mathrm{~g}$ peptone and $0.04 \mathrm{mg} \mathrm{N}$-dodecyl-N, N dimethyl-3-ammonio-1-propanesulfonate (Zwittergent) (Camper et al., 1985), followed by sonication for $5 \mathrm{~min}$ to assist the release of the bacteria from the sediment. Dilutions were prepared in triplicate series of $1 / 4$ strength Ringers solution, followed by pre-enrichment in BPW, enrichment in RV broth and confirmation on XLD agar as described above. The MPN table (Beliaeff and Mary, 1993) was used to estimate the level of bacteria in each sample by scoring all dilutions yielding black colonies as presumptive Salmonella positive. Single black colonies were selected and examined by fluorescence microscopy to verify the presence of the tagged isolate after enumeration.

\section{Results}

\section{Chromosomal tagging of a Salmonella isolate}

Several Salmonella were obtained from the river sediment and one $S$. ser. Typhimurium isolate sensitive to both ampicillin and kanamycin was selected for tagging with $g f p$. After tri-parental mating pSM1695 was successfully introduced into $S$. ser. Typhimurium as confirmed by initial resistance to both ampicillin and kanamycin. Two fluorescing tri-transconjugants were obtained, confirmed sensitive to ampicillin by replica plating, and were assumed to harbour genomic integrations of the pUT mini-Tn5 $\mathrm{Km}$ transposon harbouring $g f p$. The $g f p$ gene was amplified successfully by PCR from chromosomal extracts. Southern Blot hybridisation confirmed that the $g f p$ gene had integrated into the chromosome of the tagged isolates. Neither recombinant harboured plasmid pSM1695 as determined by sensitivity to ampicillin and by absence of detectable plasmid determined by agarose gel electrophoresis of plasmid extracts. The gfp gene could also not be detected by PCR using plasmid extract.

\section{Maintenance of the gfp gene}

The stability of the GFP labelling was tested by continuous batch culturing for $30 \mathrm{~d}$ under non-selecting conditions. The GFP was expressed in all cells cultured in both LB and $1 / 10$ strength R2A as determined by fluorescence microscopy. This showed that the gfpmut3b* gene was maintained stably under both nutrient-rich and nutrient-poor conditions in all progeny.

\section{Fitness of the recombinant strains}

\section{Fitness under nutrient-rich and nutrient-poor conditions}

The tagged isolates did not display discernable growth rate or yield deficiencies when compared to the wild-type strain, both under nutrient-rich (LB broth) (Fig. 1a) and nutrient-poor $(1 / 10$ strength R2A medium) conditions (Fig. 1b). This indicated that the integration did not affect growth of the recombinant strains. GFP fluorescence was clearly visible by fluorescence microscopy in cells grown in $1 / 10$ strength R2A, showing that gfp was still expressed constitutively during growth in nutrient-limiting conditions.

\section{Phenotypic comparison}

The Biolog Phenotype Microarrays indicated 21 out of a total of 379 phenotypic changes in tagged Strain 1 in comparison to the wild-type strain, only 5 of which demonstrated impaired growth (D-aspartic acid as a carbon source and D-asparagine, $\mathrm{N}$-acetyl-D-mannosamine and inositol hexaphosphate as a nitrogen source). The recombinant was curiously able to grow on 16 additional nutrients, including inositol, bromo succinic acid, tricarballylic acid, dihydroxy fumaric acid, 2-hydroxy benzoic acid, D-tartaric acid, D,L- $\alpha$-amino caprylic acid, L-arginine, L-asparagine, xanthine, alanine-glutamine, D-mannose-1phosphate, D-mannose-6-phosphate, cysteamine-5-phosphate, $\mathrm{O}$-phospho-D-serine and D-methionine). None of these sources appear essential for growth of Salmonella, nor would they be expected to be major nutrients in the environment. The results indicated that the incorporation of the $g f p$-bearing transposon was not detrimental to the fitness of the tagged strain or its ability to utilise a range of prevalent carbon, nitrogen and sulphur sources, yet the observed phenotypic changes are intriguing.

\section{Visual evaluation of Salmonella in an established mixed culture biofilm}

After $72 \mathrm{~h}$ a 5 -strain biofilm with developed micro-colonies had formed in the acetate-containing drinking water. No fluorescence could be detected microscopically. Salmonella was found to attach to and survive in the mixed culture biofilm. Individual fluorescing cells could be visualised $24 \mathrm{~h}$ after inoculation among the mixed culture biofilm at both spiking concen- 

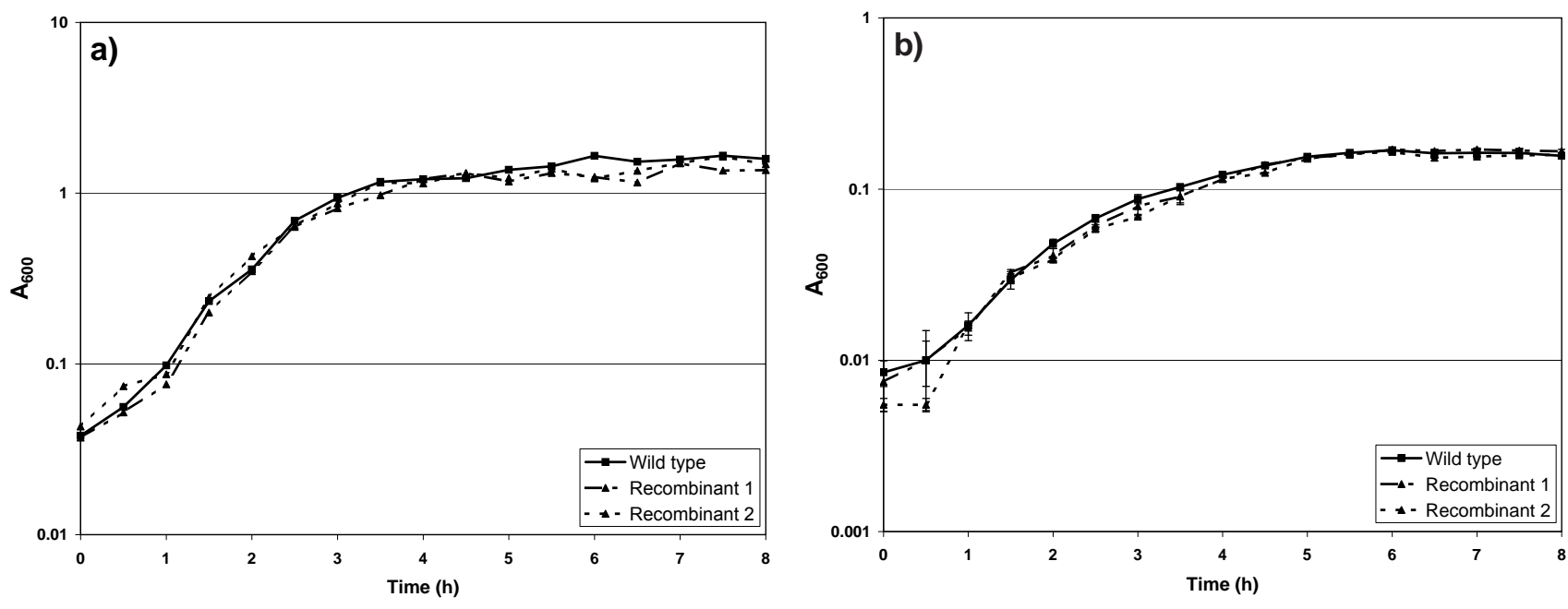

Figure 1

Growth of Salmonella Typhimurium wild-type vs. tagged strains in LB broth (a) and ${ }_{10}^{1 / 10}$ strength $R 2 A$ medium (b) at $37^{\circ} \mathrm{C}$.

The error bars denote the standard error of the mean.

tration of $10^{6} \mathrm{CFU} / \mathrm{m} \ell$ and $10^{2} \mathrm{CFU} / \mathrm{m} \ell$. Salmonella persisted in the established biofilm, forming small micro-colonies after $48 \mathrm{~h}$, and continued to persist in the established biofilm at $72 \mathrm{~h}$ (Fig. 2). The $g f p$-tagged strain, therefore, facilitated the study of the interaction of Salmonella with a consortium of other bacteria in a biofilm. All fluorescing colonies obtained following plating of serial dilutions of biofilm onto LB agar were confirmed as kanamycin-resistant Salmonella following streaking onto XLD agar, indicating a lack of interspecies transfer of $g f p$ in the biofilm.

\section{Survival of Salmonella in natural freshwater sediments}

The Salmonella recombinant introduced into a river sediment sample declined exponentially over several weeks (Fig. 3). Initially most of the inoculated CFU could be recovered using BPW followed by RV broth and XLD culturing. All Salmonella obtained displayed green fluorescence, indicating stable maintenance of the $g f p$ gene under sediment conditions. The initial rate of decline was independent of the incubation temperature. After 5 weeks the recombinants surviving at $28^{\circ} \mathrm{C}$ died, while survivors at both 8 and $16^{\circ} \mathrm{C}$ respectively persisted for a further 16 weeks before none could be detected in the sediment samples. A repeat of this experiment using fresh sediment produced similar results.

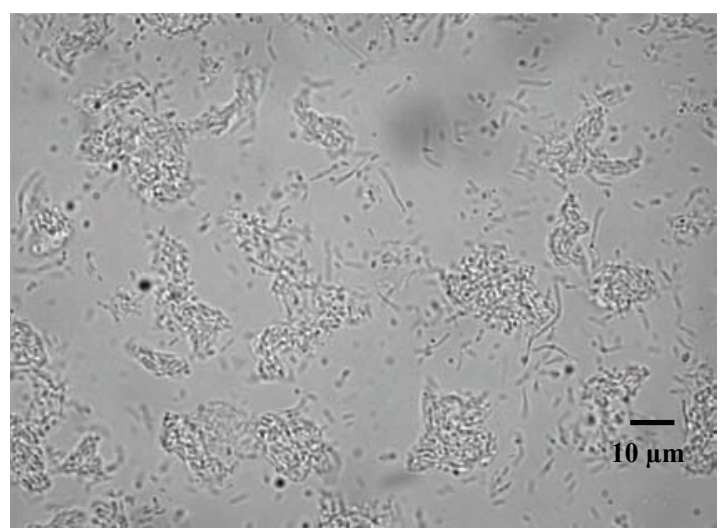

\section{Discussion}

$S$. Typhimurium is often endemic in developing countries and was commonly isolated from patients in a rural area in South Africa (Venter, 2005). Salmonella enterica serotype Typhimurium is also increasingly found to persist in a range of environments, pointing to its ability to endure in various habitats (Islam et al., 2004; Natvig et al., 2002). In this study the construction and evaluation of a $S$. Typhimurium strain tagged genomically with the gfp gene is described.

In aquatic systems bacteria may encounter low nutrient conditions, limiting the ability to express non-essential genes. The inserted gene under control of the promoter of the $r r n B$ operon (Sternberg et al., 1999) was expressed as determined by epifluorescence microscopy during growth in a variety of culture media, ranging from LB broth to $1 / 10$ strength R2A and drinking water containing $1 \mathrm{mg} / \ell$ acetate. This indicated that the gene was expressed even when cells were subjected to severe nutrient limitation and even after extended periods of growth. Fluorescence could be viewed for both cells in suspension as well as for biofilm-associated cells.

Recombinant bacteria are known to lose foreign genes in the absence of selective pressure or under stress conditions (Sobecky et al., 1992). Autecological studies or studies dealing with the biological relationship between an individual species and its environment should accurately reflect the prevailing

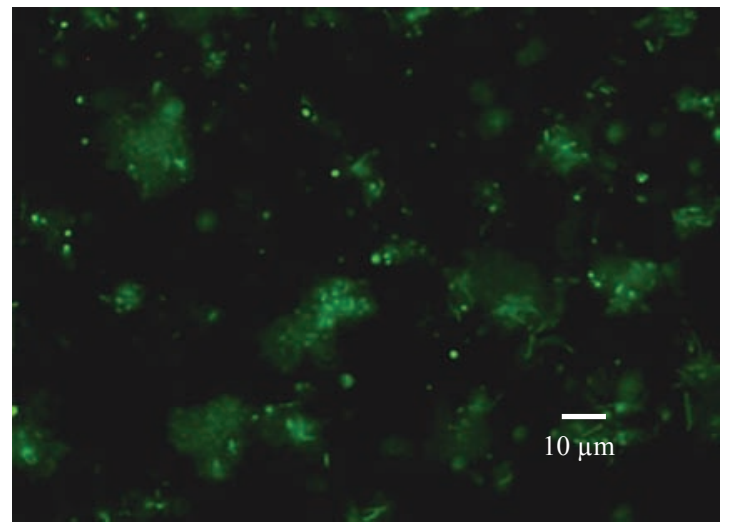

Figure 2

Mixed culture biofilm spiked with Salmonella Typhimurium of $10^{6} \mathrm{CFU} / \mathrm{ml}$ after $72 \mathrm{~h}$ viewed by phase contrast $(A)$ and fluorescence microscopy (B) 


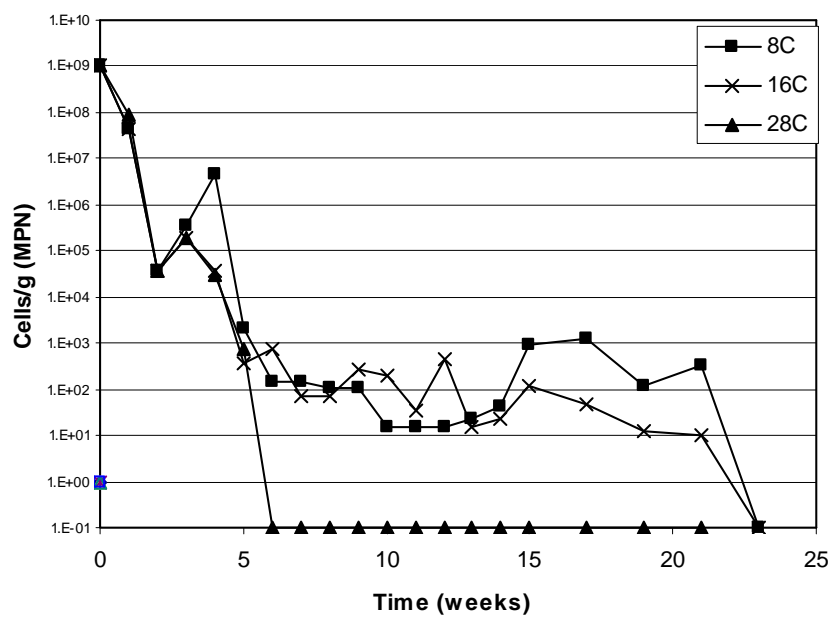

Figure 3

The effect of temperature on the survival of Salmonella Typhimurium in freshwater sediments

environmental conditions and should exclude factors foreign to the system, such as supplementation with antibiotics for selective plasmid maintenance. The recombinant $S$. Typhimurium maintained the $g f p$ gene in the absence of selective pressure in axenic broth batch culture, in competitive conditions such as biofilm and in sediment microcosms. It is therefore demonstrated to be suitable for autecological studies.

The insertion point of the mini-Tn5 transposon is selected at random, and may therefore involve the disruption of a chromosomal sequence. Environmentally important functions can thus be affected (De Lorenzo et al., 1998). The gfp-labelled recombinant was not found to be growth rate impaired in nutrient-rich or nutrient-poor medium, as growth rates of recombinant and parental strains were indistinguishable. A thorough phenotypic interrogation using the Biolog Phenotypic Microarrays indicated loss of growth on 5 nutrient sources, which are not anticipated as significant nutrient sources in aqueous systems. The gain of function for 16 nutrients cannot be explained, but may point to inactivation of a repressor. The recombinant strain was also able to form biofilms as efficiently as the wild type under pure culture conditions in drinking water supplemented with acetate (data not shown).

The $g f p$-tagged S. Typhimurium was evaluated for applications in the study of both drinking water biofilms and sediments. Salmonella was able to colonise a pre-formed drinking water biofilm, and was able to persist and grow while expressing green fluorescence. The tagged strain could also be used to study the survival of Salmonella in freshwater sediments. The GFP label could be used to verify that Salmonella isolated from the sediments during the entire study period was indeed the same clone used during the initial spiking of the sample. The results indicated that Salmonella survived for extended periods in sediments at temperatures typically associated with freshwater streams and rivers in South Africa. A sub-population of the Salmonella survived for extended periods at 8 and $16^{\circ} \mathrm{C}$ respectively, but not at $28^{\circ} \mathrm{C}$. This is in agreement with studies on the survival of various pathogenic bacteria and indicator organisms in the environment (Barcina et al., 1997; Anderson et al., 2005). While no net increase in the Salmonella culturable count was observed, the strain could still have grown in specific niches while decreasing in others due to either grazing or amensalistic challenges.

\section{Conclusions}

The gfp tagged strain of $S$. Typhimurium could therefore be used in situ to study the growth, survival and dissemination of Salmonella in water environments such as sediments or drinking water distribution systems. The tagged strain will facilitate long-term monitoring of Salmonella survival, growth and dissemination in nutrient-limited conditions and microbial communities, improving our knowledge and understanding of the ecology of this devastating pathogen in aqueous environments.

\section{Acknowledgements}

We thank JB Anderson for his kind gift of pSM1695, Raynard MacDonald for assistance with microscopy and Mulde Willemse for assistance with sediment work. This research was supported by a grant from the Water Research Commission of South Africa (WRC K5/1276) to VSB and SNV, National Research Foundation (NRF) grant 2046811 to VSB, and by the South Dakota Agricultural Experiment Station. LMB was supported by a scholarship from the NRF of South Africa.

\section{References}

AMANN RIW, LUDWIG W and SCHLEIFER K-H (1995) Phylogenetic identification and in situ detection of individual microbial cells without cultivation. Microbiol. Rev. 59 143-169.

ANDERSON KL, WHITLOCK JE and HARWOOD VJ (2005) Persistence and differential survival of fecal indicator bacteria in subtropical waters and sediments. Appl. Environ. Microbiol. 71 3041-3048.

ANDERSON JB, STERNBERG C, POULSEN LS, BJØRN SP, GIVSKOV M and MOLIN S (1998) New unstable variants of GFP for studies of transient gene expression in bacteria. Appl. Environ. Microbiol. 64 2240-2246.

BARCINA I, LEBARON P and VIVES-REGO J (1997) Survival of allochtonous bacteria in aquatic systems: a biological approach. FEMS Microbiol. Ecol. 23 1-9.

BAUDART J, LEMARCHAND K, BRISABOIS A and LEBARON P (2000) Diversity of Salmonella strains isolated from the aquatic environment as determined by serotyping and amplification of the ribosomal DNA spacer regions. Appl. Environ. Microbiol. 66 15441552.

BELIAEFF B and MARY J-Y (1993) The "most probable number" estimate and its confidence limits. Water Res. 27 799-805.

CAMPER A, BURR M, ELLIS B, BUTTERFIELD P and ABERNATHY C (1999) Development and structure of drinking water biofilms and techniques for their study. J. Appl. Microbiol. Symp. Supplement 85 1S-12S.

CAMPER A, LECHAVELLIER MW, BROADAWAY SC and McFETERS GA (1985) Evaluation of procedures to desorb bacteria from granular activated carbon. J. Microbiol. Methods 3 187-198.

CHALFIE M, TU Y, EUSKIRCHEN G, WARD WW and PRASHER DC (1994) Green fluorescent protein as a marker for gene expression. Sci. 263 802-805.

CLOETE TE and DE BRUYN EE (2001) The effect of culture media on antigenic expression in sulphate-reducing bacteria. Curr. Microbiol. 42 305-309.

DE LORENZO V, HERRERO M, SANCHEZ JM and TIMMIS KN (1998) Mini-transposons in microbial ecology and environmental biotechnology. FEMS Microbiol. Ecol. 27 211-224.

DE LORENZO V, HERRERO M and TIMMIS KN (1990) Mini-Tn5 transposon derivatives for insertion mutagenesis, promoter probing and chromosomal insertion of cloned DNA in Gram-negative bacteria. J. Bacteriol. 172 6568-6572.

EBERL L, SCHUKZE R, AMMENDOLA A, GEISENBERGER O, ERHART R, STERNBERG C, MOLIN S and AMANN R (1997) Use of green fluorescent protein as a marker for ecological studies of activated sludge communities. FEMS Microbiol. Lett. 149 77-83. 
FIGURSKI DH and HELINSKI DR (1979) Replication of an origincontaining derivative of plasmid RK2 dependent on a plasmid function provided in trans. Proc. Natl. Acad. Sci. USA 76 1648-1652.

FRANA TS and CARLSON SA (2001) Development and use of a plasmid encoding green fluorescent protein in multiple antibiotic resistant Salmonella. BioTechniques 30 28-32.

GANNON VP, GRAHAM TA, READ S, ZIEBELL K, MUCKLE A, MORI J, THOMAS J, SELINGER B, TOWNSHEND I and BYRNE J (2004) Bacterial pathogens in rural water supplies in Southern Alberta. Canada. J. Toxicol. Environ. Health A 67 1643-1653.

HO BSW and TAM T-Y (2000) Rapid enumeration of Salmonella in environmental waters and wastewater. Water Res. 43 2397-2399.

HUNTER PR (1997) Water-Borne Diseases: Epidemiology and Ecology. John Wiley and Sons, Chichester.

ISLAM M, MORGEN J, DOYLE MP, PHATAK SC, MILLNER P, JIANG X (2004) Persistence of Salmonella enterica serovar Typhimurium on lettuce and parsley and in soils on which they were grown in fields treated with contaminated manure composts or irrigation water. Foodborne Pathog. Dis 1 27-35.

LIM CH and FLINT KP (1989) The effects of nutrients in the survival of Escherichia coli in lake water. J. Appl. Bacteriol. 66 559-569.

MEIKLE A, GLOVER LA, KILLHAM K and PROSSER JI (1994) Potential luminescence as an indicator of activation of genetically modified Pseudomonas fluorescens in liquid culture and in soil. Soil Biol. Biochem. 26 747-755.

MOGANEDI KLM, GOYVAERTS EMA, VENTER SN and SIBARA MM (2007) Optimisation of PCR-invA primers for the detection of Salmonella in drinking and surface waters following a pre-cultivation step. Water SA 33 (2) 195-202.

MÖLLER S, STERNBERG C, ANDERSEN JB, CHRISTENSEN BB, RAMOS JL, GIVSKOV M and MOLIN S (1998) In situ gene expression in mixed culture biofilms evidence of metabolic interaction between community members. Appl. Environ. Microbiol. 64 721-732.

MOORE BC, MARTINEZ E, GAY JM and RICE DH (2003) Survival of Salmonella enterica in freshwater and sediments and transmission by the aquatic midge Chironomus tentans (Chironomidae: Diptera). Appl. Environ. Microbiol. 69 (8) 4556-4560

NATVIG EE, INGHAM SC, INGHAM BH, COOPERBAND LR, ROPER TR (2002) Salmonella enterica serovar Typhimurium and Escherichia coli contamination of root and leaf vegetables grown in soils with incorporated bovine manure Appl. Environ. Microbiol. 68 2737-2744

O'SHEA ML and FIELD R (1992) Detection and disinfection of pathogens in storm-generated flows. Can. J. Microbiol. 38 267-276.

SOBECKY PA, SCHELL MA, MORAN MA and HODSON RE (1992) Adaptation of model genetically engineered microorganisms to lake water: Growth rate enhancements and plasmid loss. Appl. Environ. Microbiol. 58 3630-3637.

STERNBERG C, CHRISTENSEN BB, JOHANSEN T, NIELSEN AT, ANDERSEN JB, GIVSKOV M and MOLIN S (1999) Distribution of bacterial growth activity in flow chamber biofilms. Appl. Environ. Microbiol. 65 (9) 4108-4117.

SZEWZYK U, SZEWZYK R, MANZ W and SCHLEIFER K-H (2000) Microbiological safety of drinking water. Annu. Rev. Microbiol. 54 81-127.

TOMBOLINI R, UNGE A, ELLEN D, DE BRUIJN F and JANSSON JK (1997) Flow cytometric and microscopic analysis of GFP-tagged Pseudomonas fluorescens bacteria. FEMS Microbiol. Ecol. 22 1728.

VALDIVIA RH, HROMOCKYI AE, MONACK D, RAMAKRISHNAN L and FALKOW S (1996) Applications for the green fluorescent protein (GFP) in the study of host-pathogen interaction. Gene. 17347 52.

VENTER SN (2005) Origin, Fate and Clinical Relevance of Water-borne Pathogens Present in Surface Waters. WRC Report No. 1398/1/05. Water Research Commission, Pretoria, South Africa.

WINFIELD MD and GROISMAN EA (2003) Role of nonhost environments in the lifestyles of Salmonella and Escherichia coli. Appl. Environ. Microbiol. 69 (7) 3687-3694. 